\title{
Seasonal dynamics of picoplankton in shelf waters of the southern Bay of Biscay
}

\author{
Alejandra Calvo-Díaz*, Xosé Anxelu G. Morán \\ Instituto Español de Oceanografía (IEO), Centro Oceanográfico de Xixón, Camín de L'Arbeyal, s/n, 33212 Xixón, Spain
}

\begin{abstract}
Seasonal variations in autotrophic and heterotrophic picoplankton community structure were studied by flow cytometry at 3 shelf stations in the central Cantabrian Sea (southern Bay of Biscay), from April 2002 to April 2003. A marked seasonality was found for autotrophs, with cyanobacteria (Synechococcus and Prochlorococcus) being more important in nutrient-depleted waters (June to October, $75 \pm 3 \%$ of picophytoplanktonic cells) whereas picoeukaryotes clearly dominated in terms of biomass during the rest of the year $(82 \pm 2 \%)$. The absence of Prochlorococcus in spring and summer seems to be related to hydrology rather than to nutrient conditions. Under stratification the maximum abundance of cyanobacteria was found above the nutricline, in contrast to picoeukaryotes. Autotrophic groups cell size was strongly influenced by nutrient conditions while chlorophyll a fluorescence varied in parallel to irradiance. Heterotrophic bacteria were less variable than picophytoplankton and high nucleic acid content (HNA) cells dominated the community in winter and spring $(64 \pm 1 \%)$ but only at depth during the rest of the year. A similar response of low nucleic acid content (LNA) bacteria to environmental conditions suggests they are, at least partially, metabolically active, in contrast to the commonly held view that they are a homogeneous group of dead or dormant cells. A larger mean size of LNA compared with HNA bacteria was consistently observed in winter and spring. Regardless of variations in abundance and group composition, the great constancy of the picoplanktonic contribution to integrated algal biomass $(17 \pm 2 \%)$ over the seasonal cycle outlines the importance of picophytoplankton also in coastal zones.
\end{abstract}

KEY WORDS: Autotrophic picoplankton · Heterotrophic bacteria $\cdot$ Seasonal dynamics $\cdot$ Continental shelf · Cantabrian Sea · Bay of Biscay

Resale or republication not permitted without written consent of the publisher

\section{INTRODUCTION}

Our view of the structure and function of planktonic ecosystems has changed since the discovery of the marine cyanobacteria Synechococcus spp. (Waterbury et al. 1979) and Prochlorococcus spp. (Chisholm et al. 1988). Together with a great diversity of autotrophic eukaryotes and virtually all heterotrophic prokaryotes, these 3 ecologically different groups comprise the smallest size-class of plankton or picoplankton (cells $<2 \mu \mathrm{m})$.

The importance of picoplankton in vast areas of the open ocean, where it dominates phytoplankton standing stocks and, to a lesser extent, production, has been extensively demonstrated ( $\mathrm{Li}$ et al. 1983, Zubkov et al. 1998, 2000, Fernández et al. 2003). On an annual basis, it has been found that cyanobacteria dominate picophytoplankton abundance in the Atlantic Ocean (Sargasso Sea: DuRand et al. 2001) and in several Pacific Ocean locations (subtropical: Campbell et al. 1997, western subarctic: Liu et al. 2002, coastal California waters: Worden et al. 2004), while picoeukaryotes were the major contributors in terms of biomass (Worden et al. 2004). However, relatively little is known on the significance of picoplankton in shelf waters, where picoplankton is generally subjected to a higher environmental variability than in offshore waters. Previous studies have shown the importance of local patterns, such as oceanic currents and frontal areas (Miyazono et al. 1992, Jiao et al. 2002), as well as an overall lower relative importance of picoplankton compared with open waters (Partensky et al. 1999, Li \& Harrison 2001). Along the European 
shelves, the structure of the picoplanktonic community has been studied in detail in semi-enclosed seas such as the Baltic (Jochem 1988, Kuosa 1991) and the Mediterranean (Agawin et al. 1998), but not in open regions affected by the macroscale circulation patterns of the North East Atlantic. To the best of our knowledge only El Hag \& Fogg (1986), Joint et al. (1986) and Rodríguez et al. (2000) have provided data on the autotrophic component of the Irish Sea, the Celtic Sea and the English Channel, respectively.

The Bay of Biscay is a typical temperate ecosystem, characterized by an annual maximum of phytoplanktonic biomass and production in late winter/spring and minimum values in summer. The spring to summer transition in the Cantabrian Sea in its southern limit is associated with a shift from downwelling to upwelling conditions (Fernández \& Bode 1991). The general circulation is anticyclonic (Pingree \& Le Cann 1990) but hydrodynamics along the northern and western Iberian peninsula are also affected by the presence of subtropical and saline waters transported by the Iberian poleward current (IPC, Peliz et al. 2003) in winter and early spring. An extensive survey carried out in this region at the onset of the spring bloom showed a marked coastal-offshore gradient in the abundance and size of picoplanktonic groups and an apparent confinement of Prochlorococcus to the high salinity core of the IPC (Calvo-Díaz et al. 2004). Temporal variability of heterotrophic bacteria in the region has been studied by Unanue et al. (1992) and Barquero et al. (1998) during short periods, and throughout an annual cycle by Valencia et al. (2003), who found 2 annual maxima of abundance, in spring and summer, with bacterial biomass always lower than phytoplankton biomass. Some data on autotrophic picoplankton distribution are included in Ansotegui et al. (2003) but, to our knowledge, the dynamics of the whole picoplanktonic community have not yet been examined over extended periods in the Bay of Biscay.

The present study simultaneously addresses the seasonal cycle of autotrophic and heterotrophic picoplankton in the central Cantabrian Sea, recently suggested as the northern limit of distribution of Prochlorococcus along the European Atlantic coasts (Calvo-Díaz et al. 2004). The aims of our study were (1) to describe the population dynamics of the various picoplanktonic groups and (2) to identify the relevant physico-chemical and biological factors responsible for the observed seasonal and vertical patterns in their distribution.

\section{MATERIALS AND METHODS}

Sampling was carried out from April 2002 to April 2003 at approximately monthly intervals on board RV
'José de Rioja' as part of the IEO (Instituto Español de Oceanografia) time-series project RADIALES. Samples were taken from several depths (at 5 to $10 \mathrm{~m}$ intervals for the upper $50 \mathrm{~m}$, plus at 75, 100 and $150 \mathrm{~m}$ ) between the surface and the bottom of 3 stations (Stn 1: $43.58^{\circ} \mathrm{N}, 5.61^{\circ} \mathrm{W}$; Stn 2: $43.67^{\circ} \mathrm{N}, 5.58^{\circ} \mathrm{W}$; Stn 3: $43.78^{\circ} \mathrm{N}, 5.55^{\circ} \mathrm{W}$ ) located over the shelf in a transect perpendicular to the coast in the vicinity of Xixón (Asturies, north Spain). Maximum depths were 20 (Stn 1), 100 (Stn 2) and $150 \mathrm{~m}$ (Stn 3).

Temperature, salinity and fluorescence data were acquired with a CTD SeaBird 25 equipped with a SeaPoint fluorometer. Photosynthetically active radiation (PAR) in the water column was measured with a spherical quantum sensor (biospherical QSP-2200) attached to the CTD system. Values at $1 \mathrm{~m}$ depth intervals were used to calculate the vertical light attenuation coefficient $\left(k_{d}\right)$, which was in turn used to calculate the depth of the photic layer, defined as the depth receiving $1 \%$ of surface irradiance. A stratification index (SI) was calculated as the density $\left(\sigma_{t}\right)$ gradient between the surface and $100 \mathrm{~m}$ depth. The depth of the upper mixed layer was determined as the depth where the change in density was $\geq 0.05 \mathrm{~kg} \mathrm{~m}^{-3}$ over a $5 \mathrm{~m}$ depth interval.

Water samples were taken from 51 Niskin bottles in a rosette sampler attached to the CTD. Chlorophyll $a$ concentration (chl a) was obtained after filtration of $100 \mathrm{ml}$ samples through glass fibre filters (Whatman GF/F). Filters were frozen until analysis in the laboratory. Pigments were extracted in $90 \%$ acetone for $24 \mathrm{~h}$ in the dark at $4{ }^{\circ} \mathrm{C}$ and chl a was measured with a Perkin Elmer LB-50s spectrofluorometer (Neveux \& Panouse 1987) calibrated with pure chl a. Samples for nutrients $\left(\mathrm{NO}_{3}^{-}, \mathrm{NO}_{2}{ }^{-}\right.$and $\left.\mathrm{PO}_{4}^{-}\right)$were frozen and their concentrations determined with a Technicon autoanalyzer. The nutricline depth was defined as that where the $\mathrm{NO}_{3}{ }^{-}$concentration equalled $1 \mu \mathrm{mol} \mathrm{l}^{-1}$. A significant correlation was found between it and the depth where $\mathrm{PO}_{4}^{-}$concentration equalled $0.1 \mu \mathrm{mol} \mathrm{l} \mathrm{l}^{-1}(\mathrm{r}=$ $0.68, \mathrm{p}<0.001, \mathrm{n}=26$ ).

Picoplankton samples $(1.8 \mathrm{ml})$ were preserved with $1 \%$ paraformaldehyde $+0.05 \%$ glutaraldehyde except for November 2002 samples, which were fixed with $2 \%$ glutaraldehyde. Samples were frozen at $-80^{\circ} \mathrm{C}$ until analysis in the laboratory with a FACSCalibur flow cytometer (Becton \& Dickinson) equipped with a laser emitting at $488 \mathrm{~nm}$. A solution of $1 \mu \mathrm{m}$ fluorescent latex beads (Molecular Probes) was added as an internal standard. All cellular variables were related to fluorescent beads values. For estimating the abundance of the different groups (cells ml ${ }^{-1}$ ), calibration of the cytometer flow rate was performed daily (Marie et al. 1999). Aliquots of the same sample were used for the analysis of picophytoplankton $(0.6 \mathrm{ml})$ and hetero- 
trophic bacteria $(0.4 \mathrm{ml})$. Samples were analysed at high (mean: $52 \mu \mathrm{l} \mathrm{min}{ }^{-1}$ ) and low (mean: $13 \mu \mathrm{l} \mathrm{min}{ }^{-1}$ ) flow rates, respectively, until the acquisition of 10000 events occurred. Prior to analysis, heterotrophic bacteria were stained with $2.5 \mu \mathrm{M}$ SYTO-13 DNA fluorochrome (Molecular Probes: Troussellier et al. 1999).

Autotrophic cells were separated into 2 groups of cyanobacteria (Synechococcus and Prochlorococcus) and 2 groups of picoeukaryotes based in their orange (FL2, $585 \mathrm{~nm}$ ) and red (FL3, >650 nm) fluorescence and light scatter at $90^{\circ}$ (SSC, side scatter) signals. The 2 groups of picoeukaryotes, distinguished according to their relative SSC signals, will be hereinafter referred to as 'small' and 'large' eukaryotes. Two groups of heterotrophic bacteria were distinguished based on their relative green fluorescence (FL1, $530 \mathrm{~nm}$ ) as a proxy for nucleic acid content, referred to as high nucleic acid (HNA) and low nucleic acid (LNA) bacteria.

In order to estimate biovolume, an empirical calibration between SSC and cell diameter (Fig. 1) was performed with water from the same stations and a nearby coastal site. Care must be taken when converting SSC signals to size values, since variations in SSC without changes in size can be caused by the presence of cellular inclusions (Gasol \& del Giorgio 2000) or viral infections (Brussaard et al. 1999). However, SSC was preferred to forward scatter (FSC) because of the better fit of the corresponding Model I linear regression. Mean cell diameters of the different groups were obtained after sequential filtration through polycarbonate filters ranging from 0.2 to $3.0 \mu \mathrm{m}$ pore-size, as described in detail by Zubkov et al. (1998). A spherical shape was assumed for all groups. Picoplankton biomass was finally calculated by using the following volume-tocarbon conversion factors: $350 \mathrm{fg} \mathrm{C} \mathrm{mm}^{-3}$ for hetero-

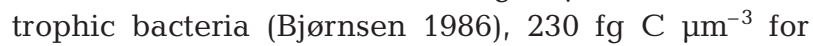

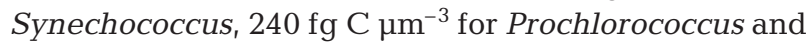

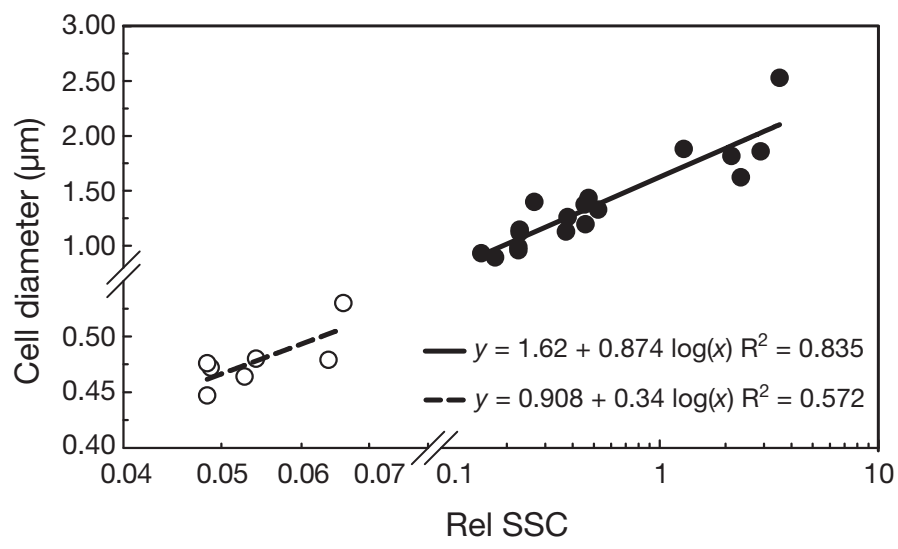

Fig. 1. Linear regression models used to convert relative light side scatter (SSC) data to cell diameter of picophytoplankton (•) and heterotrophic bacteria (O)
$237 \mathrm{fg} \mathrm{C} \mathrm{mm}^{-3}$ for picoeukaryotes (Worden et al. 2004). Total phytoplankton biomass was estimated from chl a measurements assuming a constant $\mathrm{C}$ :chl a ratio of 50 (mg:mg). According to previous work (Barquero et al. 1998) this ratio varies little in the study area.

Data were log-transformed in order to attain normality and homogeneity of variances. Statistical analyses were made with Statistica software (StatSoft). Oneway ANOVAs and post-hoc Student-Newman-Keuls (SNK) tests were applied to detect differences in picoplankton distribution and cell size along the coastal-offshore gradient represented by the 3 stations sampled. Since all variables were equally subject to measurement errors, Model II regression analysis (Ricker 1973) was performed together with the more common Model I when discussing the significance of equation slopes. Mean values provided were either integrated or averaged for the photic layer at each station, except where otherwise indicated. Depths of maximum abundance were only calculated for Stns 2 and 3. Finally, averages for the continental shelf (see Table 1) were calculated by weighting measurements at each station and their relative distance to the coastline and the shelf-break isobath (200 m).

\section{RESULTS}

\section{Hydrography and chlorophyll a}

The study area displayed the typical hydrographic conditions of temperate coastal zones (Mann \& Lazier 1991). Overall, a well-mixed water column was found from November through April, whereas marked stratification was detected in the summer months, with a thermocline located at $\sim 20 \mathrm{~m}$ depth and up to $7^{\circ} \mathrm{C}$ temperature difference between the surface and deep waters (Fig. 2). The highest $\left(20.1^{\circ} \mathrm{C}\right)$ and lowest $\left(12.0^{\circ} \mathrm{C}\right)$ surface temperatures were reached in August and February, respectively. Salinity was less variable although haline stratification due to the presence of low salinity waters at the surface was occasionally observed, especially in winter (Fig. 2). High salinities (>35.7) were observed in depth in April 2002. These high values are characteristic of the IPC which occupied most of the water column during the 3 mo prior to this sampling. Potential density $\left(\sigma_{t}\right)$ showed a pattern similar to temperature, with a marked subsurface pycnocline during summer at the outermost stations. Low salinity surface waters in February and March caused a shoaling of the mixed layer in a temperature homogeneous water-column (Fig. 2). The mixed layer extended to the bottom from November to January, and varied between 20 and $50 \mathrm{~m}$ depth during the rest of the year (Fig. 2). The station closest to the coast 


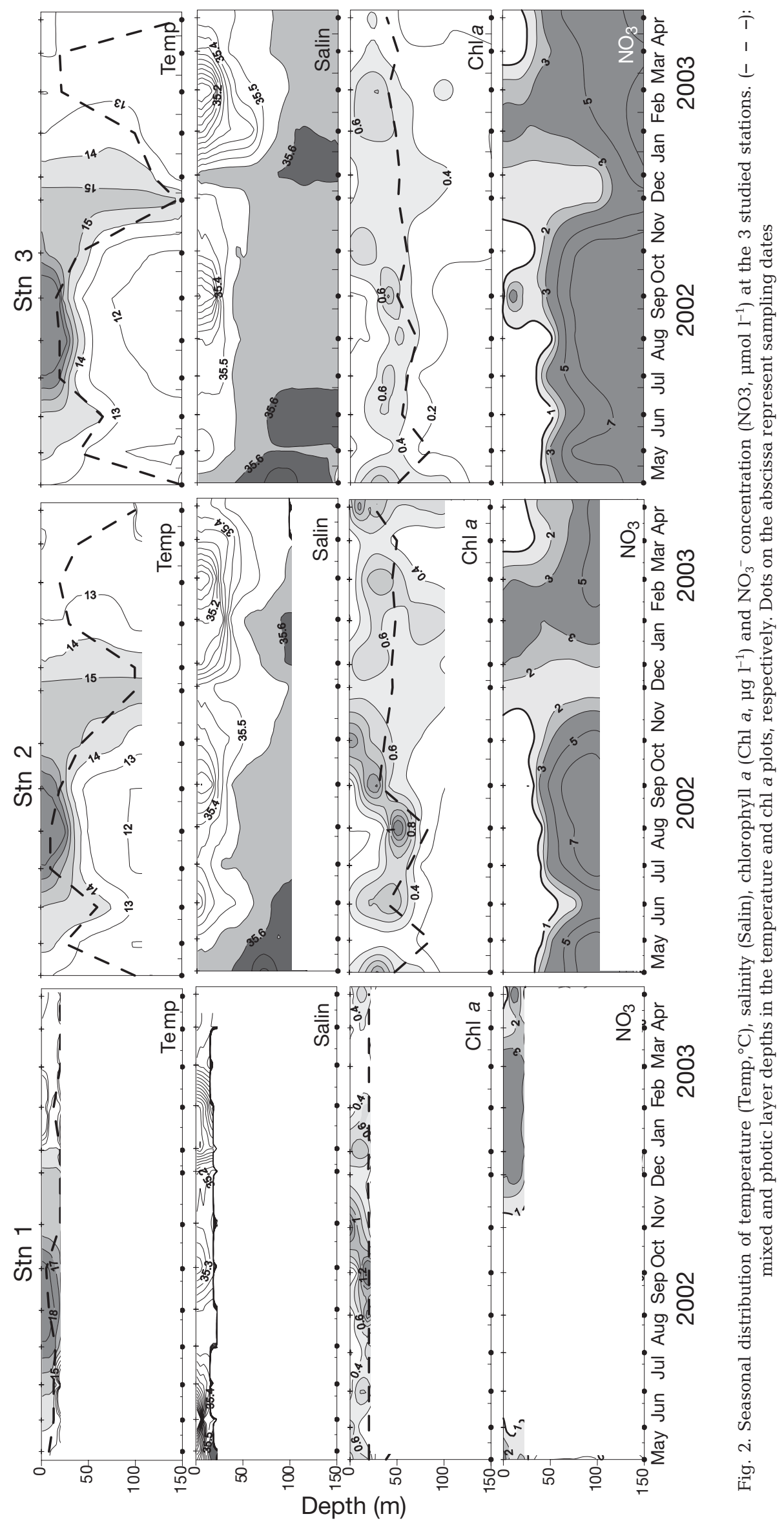


(Stn 1) was subject to tidal mixing throughout the year, yet a shallow $(<20 \mathrm{~m})$ mixed layer was observed during spring and summer. The euphotic layer depth ranged from 30 to $90 \mathrm{~m}$ at the 3 stations and was more constant ( $50 \mathrm{~m}$ ) during autumn and winter (Fig. 2).

A distinct seasonal cycle was observed for inorganic nutrient concentrations (Fig. 2), with a marked nutricline for roughly half of the year located at ca. $50 \mathrm{~m}$ depth. The nutricline was found 10 to $30 \mathrm{~m}$ below the pycnocline in summer. Nutrient concentrations were vertically homogeneous from autumn through winter, with $\left[\mathrm{NO}_{3}{ }^{-}\right]$frequently exceeding $1.5 \mu \mathrm{mol} \mathrm{l^{-1 }}$ at the surface.

Photic layer averaged chl a (range 0.22 to $1.03 \mu \mathrm{g} \mathrm{l}^{-1}$ ) was generally higher towards the coast, although differences among stations were not significant, reaching maxima in late summer and early autumn. Its vertical distribution (Fig. 2) was homogenous from November through January, with a conspicuous subsurface maximum at a depth not significantly different from that of the nutricline (paired $t$-test, $\mathrm{p}=0.31, \mathrm{n}=10$ ) from May to September.

\section{Abundance}

The cyanobacterium Prochlorococcus was present in the sampled zone only from September 2002 to February 2003 (Fig. 3). Mean abundance during that period was $7.79 \pm 1.04 \times 10^{3}$ cells ml $^{-1}$, with a maximum of 7.89 $\times 10^{4}$ cells ml ${ }^{-1}$ in September (Stn 3, $20 \mathrm{~m}$ ). Its abundance decreased gradually from the beginning of winter until its complete disappearance in March. Its vertical distribution (Fig. 4) showed maximum abundance at the surface in September and October, but subsurface maxima from November to January (surface vs. weighted photic layer abundances, paired $t$-test, $\mathrm{p}=0.03, \mathrm{n}=8$ ). In contrast, the vertical distribution of Synechococcus was more uniform throughout the year. Synechococcus (mean abundance $1.44 \pm 0.13 \times 10^{4}$ cells $\mathrm{ml}^{-1}$ ) showed markedly higher abundances during summer, with a maxima in September of $1.49 \times 10^{5}$ cells $\mathrm{ml}^{-1}$ (Stn $\left.3,30 \mathrm{~m}\right)$. In spring, this cyanobacterium dropped to values $<10^{2}$ cells $\mathrm{ml}^{-1}$. During stratification (May to September), the maximum abundance of Synechococcus was shallower than the nutricline (paired $t$-test, $\mathrm{p}=0.002, \mathrm{n}=10$ ). Synechococcus consistently outnumbered Prochlorococcus during their cooccurrence, with the exception of November.

Numbers of picoeukaryotes were less variable than those of cyanobacteria. Slightly different seasonal patterns were observed for the 2 groups (small and large) of picoeukaryotes. Small picoeukaryotes dominated in abundance during the whole sampling period and were relatively more homogeneous than the large group (mean $5.50 \pm 0.30 \times 10^{3}$ cells ml ${ }^{-1}$ ). They showed relative peaks in late winter, early spring and summer, with a maximum of $3.88 \times 10^{4}$ cells ml $\mathrm{m}^{-1}$ in August (Stn 1, $20 \mathrm{~m}$ ). Large picoeukaryotes (mean $1.30 \pm 0.11 \times$ $10^{3} \mathrm{cells} \mathrm{ml}^{-1}$ ) attained maximum values in late summer and early autumn $\left(1.19 \times 10^{4}\right.$ cells ml $^{-1}$ in October, Stn 2, $0 \mathrm{~m}$ ). Their vertically homogeneous distribution was similar to that of Synechococcus in mixing conditions (Fig. 4) (surface vs. weighted photic layer abundances, paired $t$-test, $\mathrm{p}>0.05, \mathrm{n}=9$ ). However, they reached higher depths than Synechococcus during summer stratification and there was no significant difference between the depth of their abundance maximum and that of the nutricline.

Overall, Synechococcus accounted for $60 \pm 4 \%$ of total picophytoplanktonic cell numbers and both genera of cyanobacteria dominated this community except from February to May, when picoeukaryotes accounted for $73 \pm 5 \%$ of autotrophic cells (see Fig. 10D-F). A significant correlation was found between the cyanobacteria:picoeukaryotes abundance ratio at the surface and the index of stratification $(\mathrm{r}=$ $0.62, \mathrm{p}<0.001, \mathrm{n}=26$ ), likely derived from the different seasonality observed for both types of cells. This significant correlation, together with the consistent seasonal variation of SI, suggest that this ratio (see Fig. 10D-F, dashed line) could be readily used as an index of stratification in these waters.

Total abundance of heterotrophic bacterioplankton, with an average of $5.01 \pm 0.17 \times 10^{5} \mathrm{cells} \mathrm{ml}^{-1}$, was relatively homogeneous, with lower values in winter although without any clear seasonal pattern (Fig. 3). The highest values were observed in September and October at Stn $1\left(1.8 \times 10^{6}\right.$ cells ml ${ }^{-1}$ in September, $0 \mathrm{~m})$. Their vertical distribution was rather uniform during most of the year, with a slight decrease in depth in summer (Fig. 4F). Different temporal patterns were found for the 2 groups of heterotrophic bacteria. HNA bacteria accounted for $64 \pm 1 \%$ of total numbers in winter and spring (Fig. 3). During the rest of the year this group was dominant only at depth, with total integrated numbers roughly equally shared between both groups ( $48 \pm 1 \%$ HNA bacteria).

\section{Cell size and fluorescence}

With all data pooled, the coefficients of variation of cell size were very similar for all autotrophic groups (9 to $10 \%$ ). Cellular size ranges were 0.53 to $0.96 \mu \mathrm{m}$ for Prochlorococcus, 0.72 to $1.15 \mu \mathrm{m}$ for Synechococcus, 1.00 to $1.68 \mu \mathrm{m}$ for small picoeukaryotes and 1.43 to $2.73 \mu \mathrm{m}$ for large picoeukaryotes. However, different seasonal patterns were observed for each group (Fig. 5A-D). Maximum sizes of cyanobacteria and small pico- 


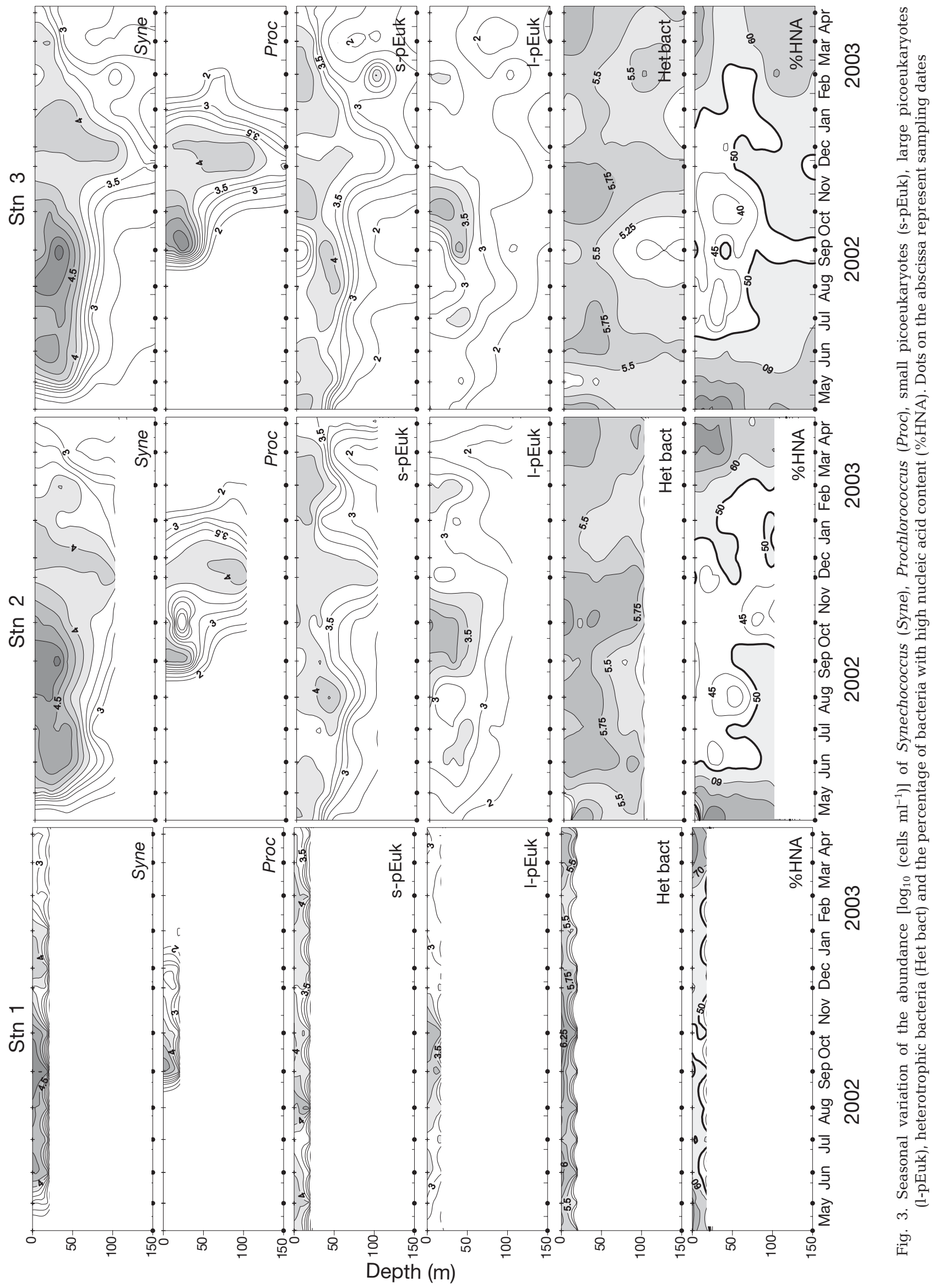



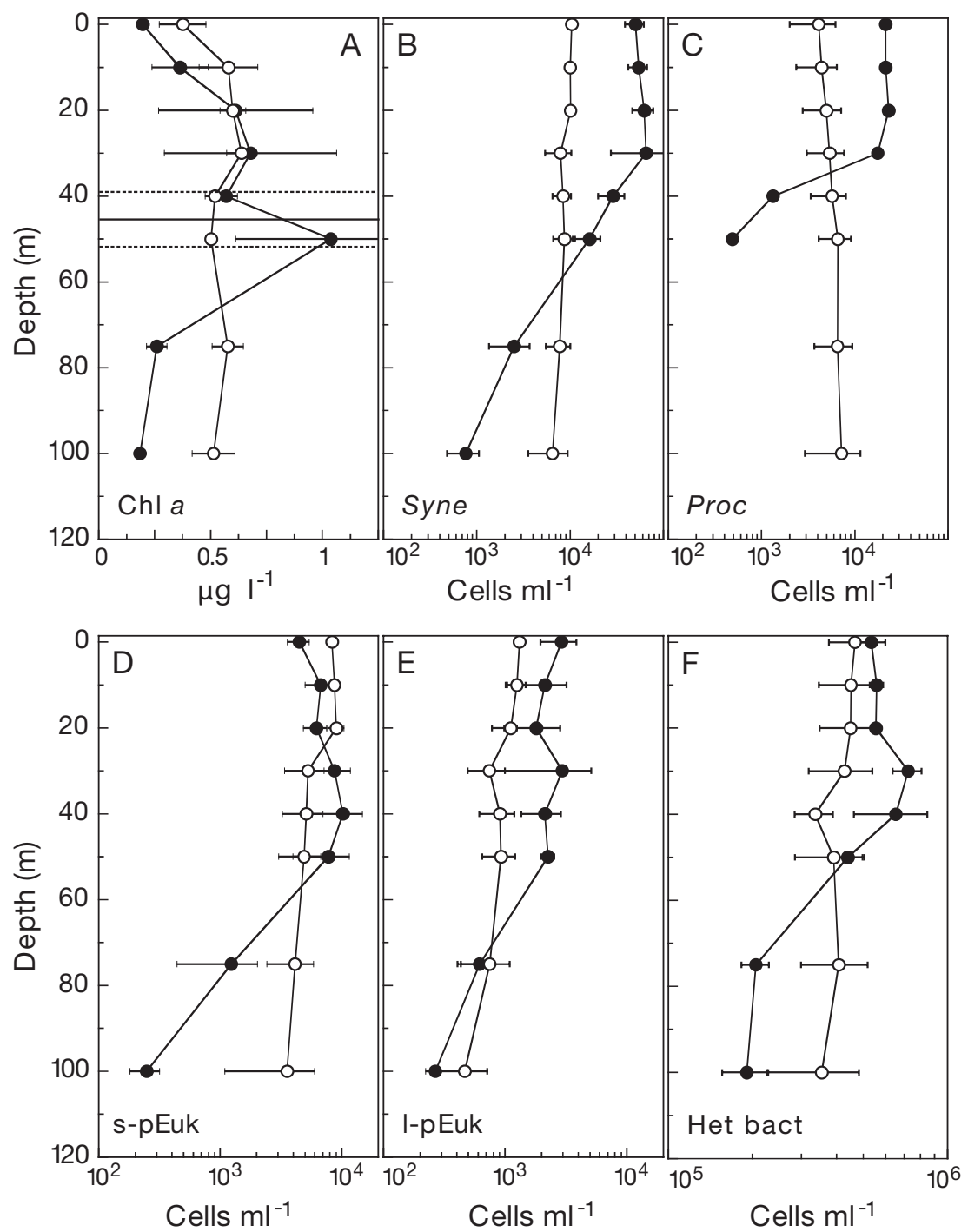

Fig. 4. Vertical profiles (mean $\pm \mathrm{SE}$ ) of chl a concentration $\left(\mu \mathrm{g} \mathrm{l}^{-1}\right.$ ) and picoplankton abundance (cells $\mathrm{ml}^{-1}$ ) at Stn 2 during stratified (July to September 2002, •) and mixing conditions (November 2002 to January 2003, o). The Prochlorococcus stratification profile shows only September data (see the text for details). Horizontal lines in the chl a plot represent mean $\pm \mathrm{SE}$ of the nutricline depth during the stratification period. Picoplankton group abbreviations as in Fig. 3

eukaryotes occurred in November. The cell size of both cyanobacteria remained high until April, with minimal diameters in summer and a gradual increase till November (Fig. 5A,B). Small picoeukaryotes tended to gradually increase in size from April to November (Fig. 5C). Species succession might underlie the saw-teeth pattern found for large picoeukaryotes (Fig. 5D).

Vertical profiles of picophytoplankton cell size were quite uniform in autumn and winter, with maxima at depth during the rest of the year (Fig. 5A,C). Sizes of cyanobacteria and small picoeukaryotes were significantly smaller above the nutricline than below
( $t$-test, $\mathrm{p}<0.001$, Fig. 6A-C). However, cell size was not significantly different when the analysis was made relative to the mixed layer depth (data not shown, $t$-test, $\mathrm{p}>0.05$ ).

Heterotrophic bacterioplankton showed no discernable seasonal patterns in cell size. A slightly higher variation of HNA bacteria (range 0.38 to $0.66 \mu \mathrm{m}$, CV $7 \%$ ) compared with LNA bacteria (range 0.33 to $0.50 \mu \mathrm{m}, \mathrm{CV} 4 \%$ ) was observed. HNA bacteria cell size remained high from summer to midwinter, with a decrease in autumn (Fig. 5E) while LNA bacteria were larger in spring and late winter, equalling and even exceeding the size of HNA bacteria, as shown in Fig. 5E and in the vertical profiles of March and April (Fig. 7).

Chl a content per cell, estimated from the relative red fluorescence (FL3), showed temporal and vertical patterns similar to size (Fig. 8A-D), although much more variable, with $\mathrm{CV}$ ranging from $38 \%$ for large eukaryotes to $68 \%$ for Synechococcus). Relative FL3 reached maxima in autumn and winter likely as a consequence of photoacclimation to overall lower ambient irradiances. All groups showed lower values at the surface than at depth in summer (see the vertical profile of small picoeukaryotes in Fig. 8C). The great increase in cyanobacteria and picoeukaryotes size and chl a content observed in November 2002 (Figs. 5 \& 8) could be the result of using glutaraldehyde rather than paraformaldehyde + glutaraldehyde as a fixative, since the former usually resulted in relatively higher SSC signals in our samples (X. A. G. Morán \& A. CalvoDíaz pers. obs.) contrary to other authors (see references in Worden et al. 2004).

Phycoerythrin content of Synechococcus, estimated as the relative orange fluorescence (FL2), was correlated with relative FL3 ( $\mathrm{r}=0.96, \mathrm{p}<0.001, \mathrm{n}=267$ ). However, the vertical profiles displayed a high variation (Fig. 8A). From December to February the FL3:FL2 ratio was generally $<1$ and remained constant throughout the water column, but a significant increase at the surface was found during the rest of the year, suggesting the presence of physiologically differentiated populations in surface and deep waters at that time. 

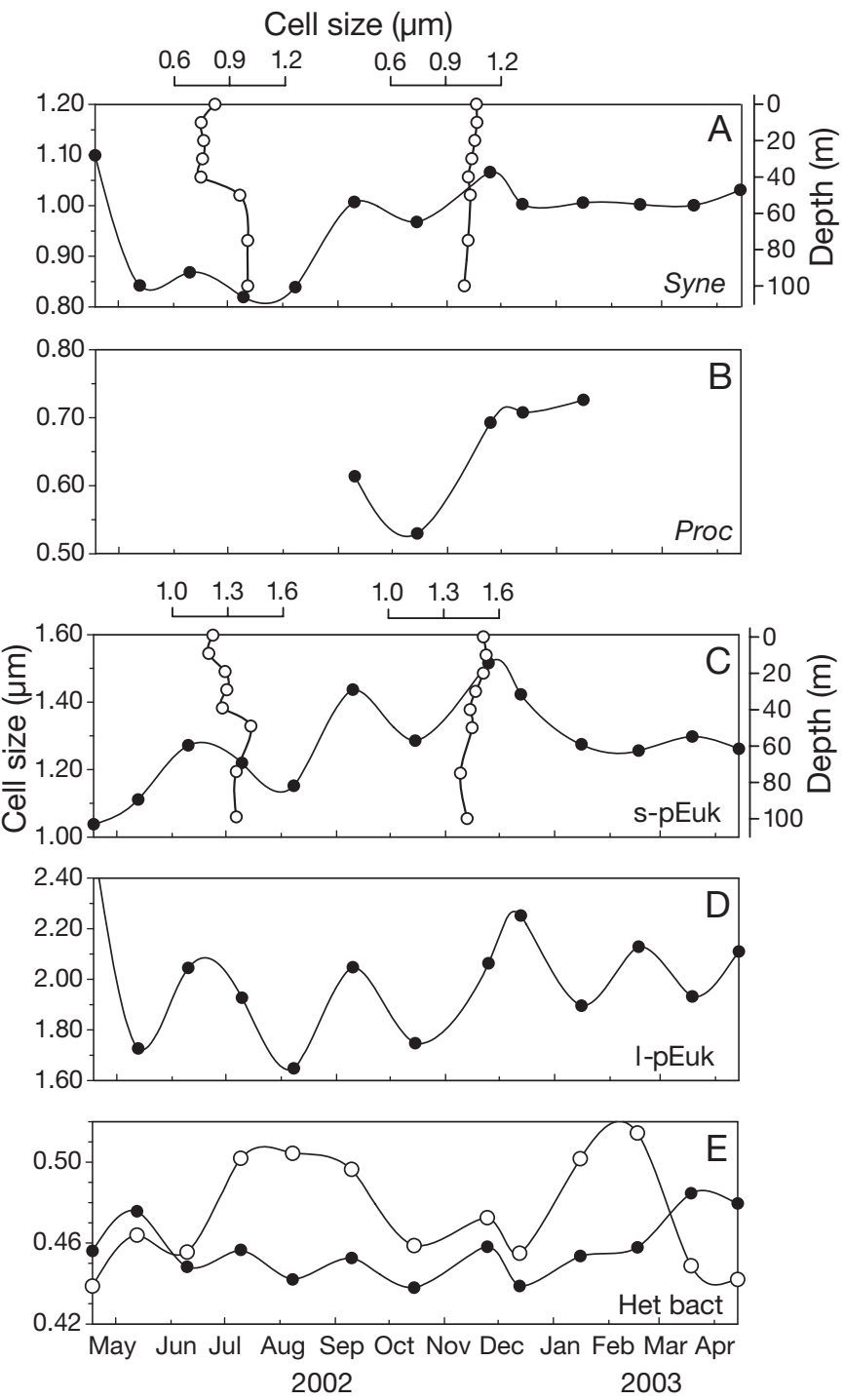

Fig. 5. Seasonal variation of cell size at the surface of Stn 2. Vertical profiles of Synechococcus and small picoeukaryotes in July and November 2002 are also shown in the corresponding plots. Filled and open symbols in (E) represent LNA (low nucleic acid content) and HNA (high nucleic acid content) bacteria, respectively. Picoplankton group abbreviations as in Fig. 3

\section{Coastal-offshore variability}

Picoeukaryotes were more abundant in the coast than in outer shelf waters (ANOVA, $\mathrm{p}<0.05$; SNKtest, small picoeukaryotes Stn $1>$ Stn $2=$ Stn 3; large picoeukaryotes Stn $1>\operatorname{Stn} 2>\operatorname{Stn} 3$ ), while the opposite, although not significant, trend was found for Prochlorococcus, with abundances in the outer shelf station about 2-fold those at Stn 1. Synechococcus and large picoeukaryotes tended also to be larger towards the coast (large picoeukaryotes, ANOVA, $\mathrm{p}<0.05$;
SNK-test, $\operatorname{Stn} 1=\operatorname{Stn} 2>\operatorname{Stn} 2=\operatorname{Stn} 3$ ), unlike Prochlorococcus and small picoeukaryotes, which presented higher sizes at Stn $3(\mathrm{p}>0.05)$. Relative FL3 also showed a clear spatial pattern, reaching highest values at the coastalmost stations for all groups (large picoeukaryotes, ANOVA, p $<0.05$; SNK-test, Stn $1=$ Stn $2>$ Stn $2=$ Stn 3) except for Prochlorococcus, which showed an opposite, non significant trend.

\section{Cell size $(\mu \mathrm{m})$}

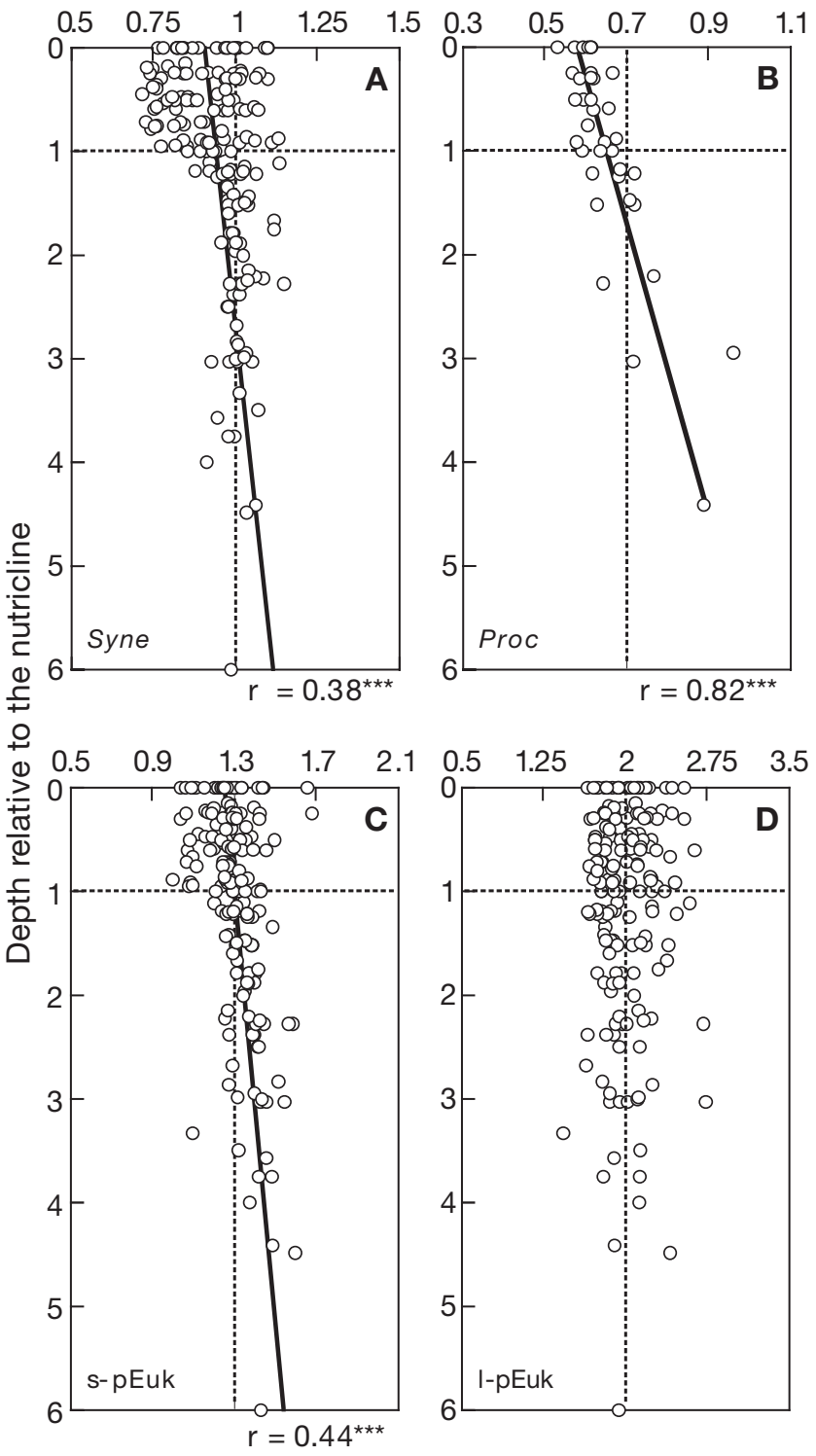

Fig. 6. Scatter plots of picophytoplankton cell size vs. depth relative to the nutricline, after Shalapyonok et al. (2001). The vertical dashed line is the mean cell size of each group. Continuous lines represent significant correlations (coefficients also given, ${ }^{* * *} \mathrm{p}<0.001, \mathrm{n}=177$, for Prochlorococcus $\mathrm{n}=36$ ). Abbreviations as in Fig. 3 


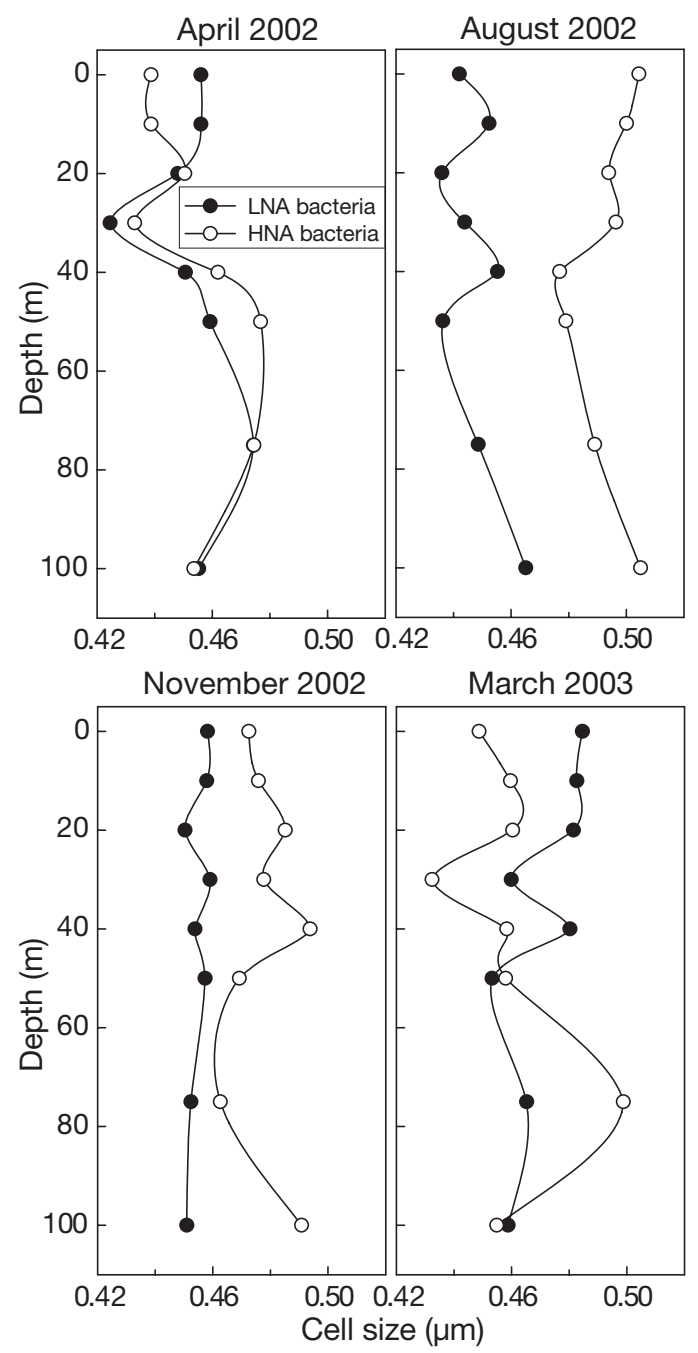

Fig. 7. Vertical profiles of cell size of HNA and LNA bacteria at Stn 2 in 4 selected months

\section{Relationships with environmental variables}

With all data pooled, abundance of autotrophic groups was negatively correlated with nutrient concentrations $\left(\mathrm{PO}_{4}{ }^{-}, \mathrm{r}=-0.31\right.$ to $-0.76 ; \mathrm{NO}_{3}{ }^{-}, \mathrm{r}=-0.34$ to $-0.70 ; \mathrm{p}<0.01, \mathrm{n}=247$ [105 for Prochlorococcus]). A negative relationship was also found between each group's cell size and abundance ( $\mathrm{r}=-0.17$ to -0.54 , $\mathrm{p}<$ $0.01, \mathrm{n}=252$ [104 for Prochlorococcus]). Positive relationships were found between cell size and relative FL3 for all the groups ( $\mathrm{r}=0.56$ to $0.79, \mathrm{p}<0.001, \mathrm{n}=$ 247 [105 for Prochlorococcus]).

Fig. 9A shows the relationship of total picophytoplankton abundance with temperature with all data pooled $(\mathrm{r}=0.68, \mathrm{p}<0.001, \mathrm{n}=273$ ). This relationship held also for individual groups $(\mathrm{r}=0.42$ to $0.85, \mathrm{p}<$ 0.001). However, for a given station lower temperatures at depth are also coincident with light-limited conditions; hence, this or other vertically covarying factors might underlie the positive response to temperature. A similar explanation could be given for the significant negative correlations $(\mathrm{r}=-0.31$ to -0.43 , $\mathrm{p}<$ $0.01, \mathrm{n}=252$ ) observed between salinity and the abundance of all groups except Prochlorococcus $(r=-0.10$, $\mathrm{p}=0.29, \mathrm{n}=105)$. A positive relationship was also found between temperature and abundance of heterotrophic bacteria $(\mathrm{r}=0.45, \mathrm{p}<0.001, \mathrm{n}=252)$, with maximum abundance of both HNA and LNA bacteria occurring at $\sim 15^{\circ} \mathrm{C}$ (Fig. 9B).

\section{Biomass}

Mean annual biomass of picophytoplankton for the photic layer of this area of the southern Bay of Biscay was $5.21 \pm 0.69 \mathrm{mg} \mathrm{C} \mathrm{m}^{-3}$. However, the 3 stations dis-
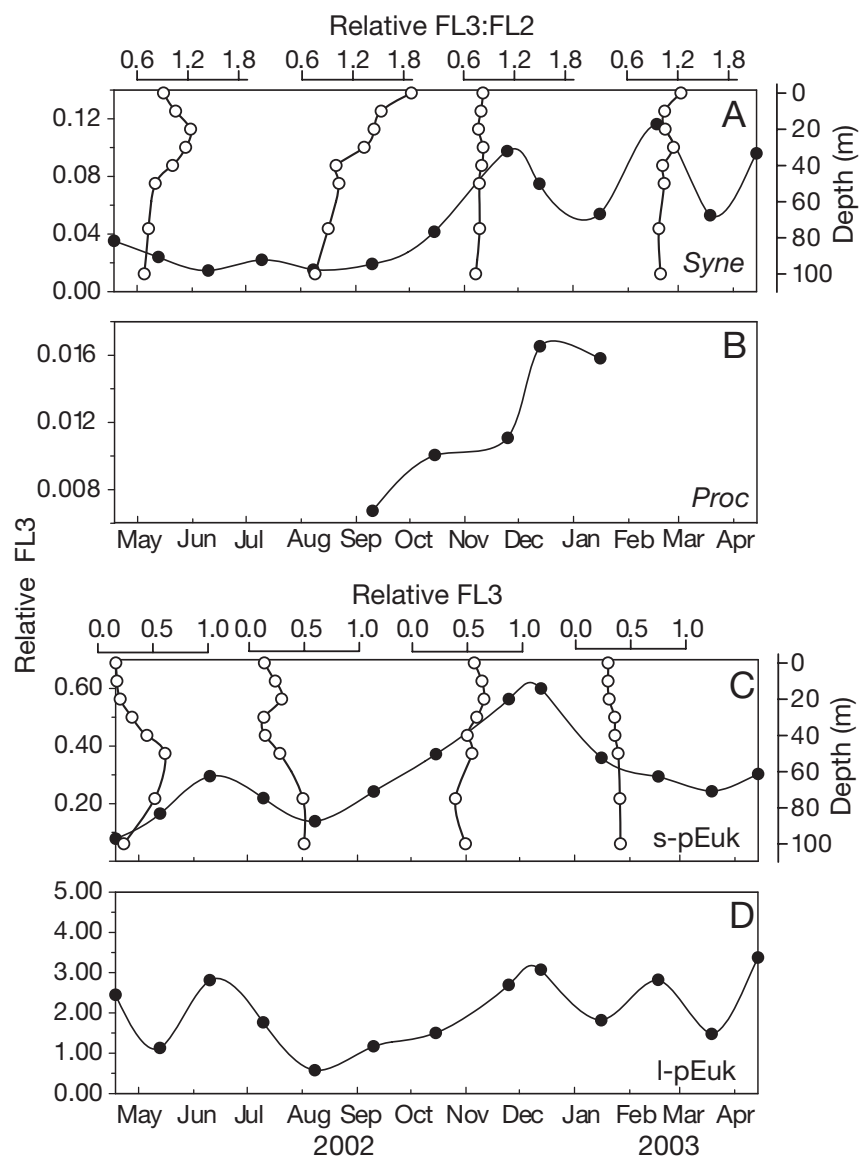

Fig. 8. Seasonal variation of chlorophyll a fluorescence (relative FL3) of the 4 picophytoplankton groups at the surface of Stn 2. Also shown are the vertical profiles of (A) the relative FL3:FL2 ratio for Synechococcus in June, September, December and March, and (C) the relative FL3 for small picoeukaryotes in May, August, November and February. Picoplankton group abbreviations as in Fig. 3 

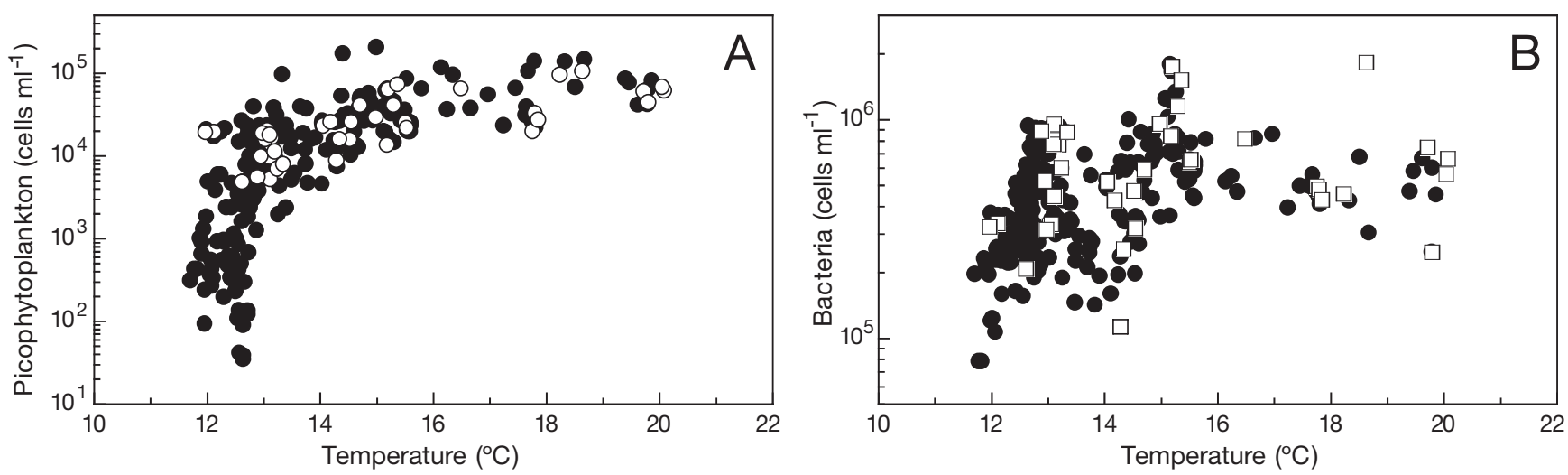

Fig. 9. Scatter plots of (A) total abundance of picophytoplankton and (B) heterotrophic bacteria vs. temperature for all data pooled. Open symbols represent surface samples

played a clear seasonality (Fig. 10A-C). Highest values were found between late summer and early autumn, with a maximum of $20 \mathrm{mg} \mathrm{C} \mathrm{m}^{-3}$ in September at Stn 1. Picoeukaryotes were always dominant (mean $3.40 \pm$ $0.33 \mathrm{mg} \mathrm{C} \mathrm{m}^{-3}$ ) except in September. They accounted for $82 \pm 2 \%$ on total biomass from November to May (Fig. 10G-I). The contribution of Prochlorococcus plus Synechococcus (range 0.002 to $11 \mathrm{mg} \mathrm{C} \mathrm{m}^{-3}$ ) was $27 \pm$ $3 \%$ on average, with minima in early spring $(<6 \%)$. Cyanobacterial contribution reached higher values from June through October ( $41 \pm 3 \%$ ) and dominated picoautotrophic biomass in September at the 3 stations and also in June and August at Stn 3 (Fig. 10I).

Table 1 shows the monthly variation of mean photic layer integrated biomass $\left(\mathrm{mg} \mathrm{C} \mathrm{m}^{-2}\right)$ of all groups in the continental shelf off Xixón. A significant correlation was found between the photic layer integrated biomasses of picophytoplankton and total phytoplankton (Fig. 11, $\mathrm{r}=0.65, \mathrm{p}<0.001, \mathrm{n}=39$ ). The slope of the log-log linear regression was not significantly different from 1 (Model I, $b=0.98$, $t$-test, $\mathrm{p}>0.05$; Model II, $b=$ $1.52,95 \%$ confidence limits: 1.18 to 1.95$)$, thus indicating that the relative contribution of picophytoplankton was relatively constant during the studied period. On an annual basis, picophytoplankton contribution to total phytoplankton biomass averaged $17 \pm 2 \%$. Maximum values of this percentage $(\sim 30 \%)$ were found in summer, and it decreased with increasing nutrient concentrations $\left(\mathrm{NO}_{3}{ }^{-} \mathrm{r}=-0.43, \mathrm{p}<0.001, \mathrm{n}=259 ; \mathrm{PO}_{4}{ }^{-}\right.$ $\mathrm{r}=-0.39, \mathrm{p}<0.001, \mathrm{n}=260$ ).

Heterotrophic bacteria accounted for a noticeable fraction of total picoplanktonic biomass ( $63 \pm 3 \%$ on average), being lower than that of picoautotrophic biomass only in September (Table 1). However, total autotrophic biomass estimated from chl a measurements exceeded the biomass of heterotrophic bacteria on most occasions (data not shown). Heterotrophic bacteria only exceeded phytoplankton biomass in
August in surface waters and sporadically at some depths in other months, especially September and March.

The biomass of all groups was significantly correlated with chl $a_{\text {, }}$ and the correlation coefficients tended to increase with the average size of the group: 0.25 for Prochlorococcus ( $\mathrm{p}=0.01, \mathrm{n}=104), 0.21$ for Synechococcus ( $\mathrm{p}=0.001, \mathrm{n}=266), 0.46$ for small picoeukaryotes $(\mathrm{p}<0.001, \mathrm{n}=268)$ and 0.54 for large picoeukaryotes $(p<0.001, n=268)$. Although causal connections are not necessarily derived from correlation analysis, along with previous observations (Calvo-Díaz

Table 1. Monthly photic layer integrated biomass $\left(\mathrm{mg} \mathrm{C} \mathrm{m}^{-2}\right)$ of the different groups averaged for the continental shelf. Syne: Synechococcus; Proc: Prochlorococcus; S-pEuk: small picoeukaryotes; L-pEuk: large picoeukaryotes; Het bact: heterotrophic bacteria. Annual means $( \pm \mathrm{SE})$ are also shown

\begin{tabular}{|c|c|c|c|c|c|}
\hline Month & Syne & Proc & S-pEuk & L-pEuk & Het bact \\
\hline \multicolumn{6}{|l|}{2002} \\
\hline Apr & 0.1 & - & 48.5 & 18.8 & 512.0 \\
\hline May & 22.7 & - & 74.6 & 25.6 & 287.6 \\
\hline Jun & 84.8 & - & 56.9 & 41.3 & 496.9 \\
\hline Jul & 87.6 & - & 71.5 & 78.4 & 525.2 \\
\hline Aug & 133.0 & - & 138.7 & 47.0 & 627.4 \\
\hline Sep & 276.0 & 23.3 & 83.0 & 152.2 & 257.7 \\
\hline Oct & 110.3 & 9.5 & 93.4 & 172.7 & 608.7 \\
\hline Nov & 43.7 & 17.3 & 115.7 & 46.7 & 505.2 \\
\hline Dec & 54.9 & 16.5 & 83.3 & 39.5 & 256.6 \\
\hline \multicolumn{6}{|l|}{2003} \\
\hline Jan & 45.4 & 1.9 & 98.1 & 45.6 & 260.2 \\
\hline Feb & 22.8 & 0.1 & 73.1 & 60.4 & 278.7 \\
\hline Mar & 17.8 & - & 65.2 & 15.1 & 587.6 \\
\hline Apr & 5.3 & - & 22.1 & 24.2 & 341.1 \\
\hline $\begin{array}{l}\text { Annual mean } \\
( \pm \text { SE })\end{array}$ & $\begin{array}{c}69.6 \\
( \pm 20.6)\end{array}$ & $\begin{array}{r}11.4^{\mathrm{a}} \\
( \pm 3.8)\end{array}$ & $\begin{array}{r}78.8 \\
( \pm 8.2)\end{array}$ & $\begin{array}{c}59.1 \\
( \pm 13.6)\end{array}$ & $\begin{array}{c}426.5 \\
( \pm 40.9)\end{array}$ \\
\hline
\end{tabular}




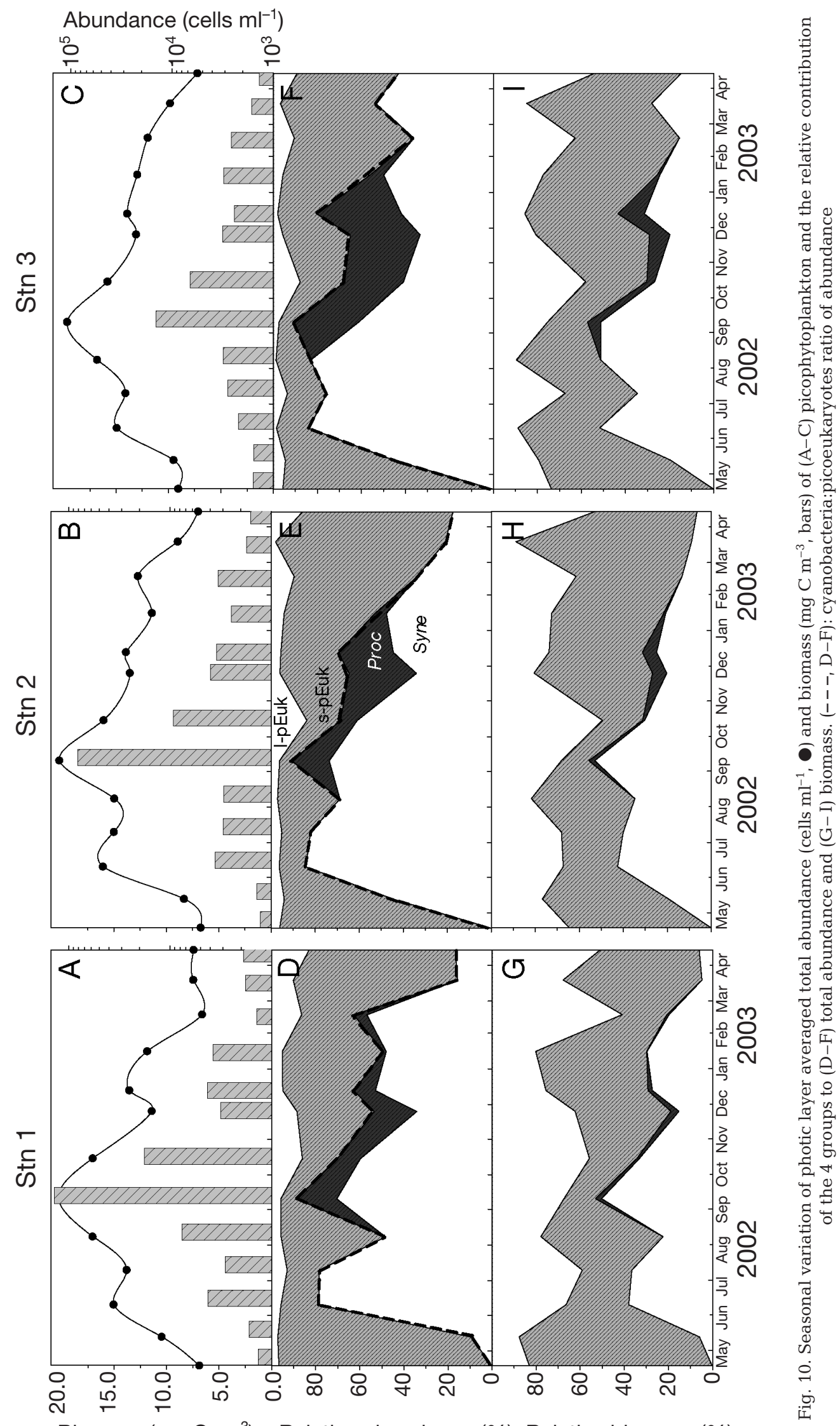

Biomass $\left(\mathrm{mg} \mathrm{C} \mathrm{m}^{-3}\right.$ ) Relative abundance (\%) Relative biomass (\%) 


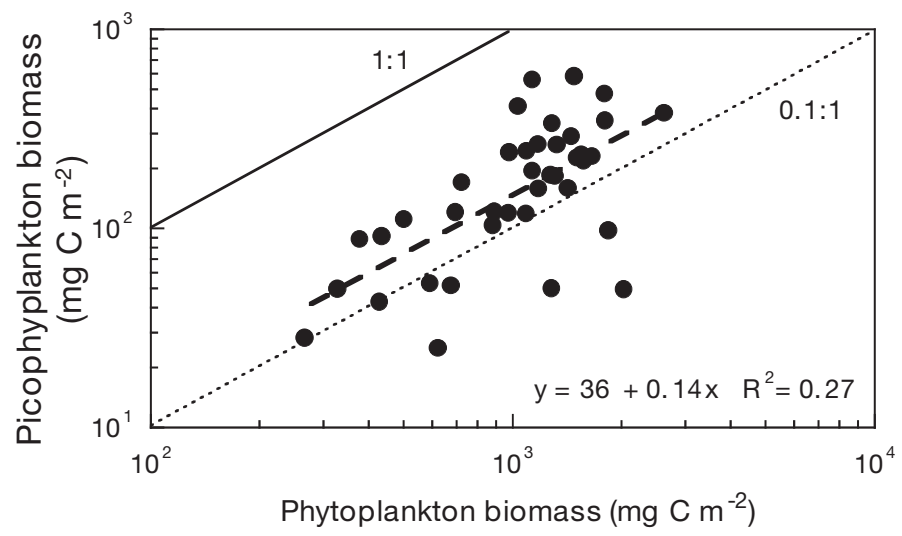

Fig. 11. Relationship between picophytoplankton and total phytoplankton photic layer integrated biomass $\left(\mathrm{mg} \mathrm{C} \mathrm{m}^{-2}\right)$ for all data pooled. (----): model I linear regression model. Lines representing 10 and $100 \%$ contribution are also shown for comparison

et al. 2004), this could suggest a higher contribution to chl $a$ of the larger-sized groups. HNA and LNA bacteria were similarly correlated with $\mathrm{chl} a(\mathrm{r}=0.36$ and 0.34 , respectively, $\mathrm{p}<0.001, \mathrm{n}=268$ ) suggesting a similar response of both types of cells to changes in phytoplankton biomass as a proxy of organic substrates supply.

\section{DISCUSSION}

\section{Seasonal variation of picoplankton abundance}

We found a clear seasonality in the picoplankton community structure associated with hydrographic conditions. Photosynthetic bacteria clearly outnumbered picoeukaryotes under stratification, in accordance with previous reports showing high cyanobacterial abundance in summer (Modigh et al. 1996, Agawin et al. 1998, DuRand et al. 2001, Liu et al. 2002). A strong relationship between temperature and Synechococcus growth rate was suggested by Agawin et al. (1998) as the origin of this seasonality in the Mediterranean Sea. However, although we also found a strong relationship between cyanobacteria and temperature, some results point to the hypothesis of Raven (1986) of the better performance of small cells in nutrient-depleted waters. The cyanobacteria:picoeukaryotes ratio decreased with increasing $\mathrm{PO}_{4}{ }^{-}$concentration and, in stratified conditions, cyanobacteria reached their abundance maximum in nutrient-depleted waters, in contrast to picoeukaryotes, which peaked at the depth of the nutricline (Fig. 4). These results suggest that, even for the limited size range of the picoplanktonic community (from $\sim 0.7 \mu \mathrm{m}$ of Prochlorococcus to $\sim 2 \mu \mathrm{m}$ of large picoeukaryotes), smaller sized cells would have an advantage over larger ones in nutrient uptake.
The 2 genera of cyanobacteria showed very similar seasonal and vertical patterns during their cooccurrence, in contrast with the results found by Campbell et al. (1997) in the Pacific and DuRand et al. (2001) in the Atlantic. During the period of nutrient limitation in surface waters (from May to October), Synechococcus was always more abundant than Prochlorococcus; as typically found in meso- and eutrophic waters (Partensky et al. 1999). Abundances of the latter were 1 to 2 orders of magnitude lower than those typical in subtropical gyres, but similar to those found by Tarran et al. (2001) in NE Atlantic waters.

As in other coastal zones (Shimada et al. 1995, Worden et al. 2004) Prochlorococcus was absent from late winter to mid-summer. We cannot conclude yet whether the presence of Prochlorococcus in these waters is due to active growth or a result of water masses advection. Although its disappearance has been related to cold conditions (Buck et al. 1996, Partensky et al. 1999), its association with the IPC in the western Cantabrian Sea (Calvo-Díaz et al. 2004) and its absence in coastal waters further north, despite its observation at considerably higher latitudes in the open ocean (Buck et al. 1996), suggest physical controls other than temperature. The persistently higher abundance of Prochlorococcus in the outer shelf, its shallower distribution compared with Synechococcus when it first appeared (Fig. 3) and its rapid decrease coincident with the period of stronger slope currents in the Bay of Biscay (Pingree \& Le Cann 1990, Koutsikopoulos \& Le Cann 1996), altogether suggest a relationship with regional hydrographic features not fully understood. The seasonality of Prochlorococcus seems to be rather constant in these waters, since it reappeared from August 2003 to February 2004, from September 2004 to January 2005, and again in September 2005 (L. Á. Suárez et al. pers. comm.). However, further studies are needed to determine why Prochlorococcus but not Synechococcus disappeared completely for such an extended period (Fig. 3).

The overall abundance of picoeukaryotes was similar to that found in other studies (Buck et al. 1996, Tarran et al. 2001) and less variable than that of cyanobacteria, in agreement with reports from other zones (Liu et al. 2002). The 2 groups of picoeukaryotes showed a different seasonality (Fig. 3), and although they were likely far from being taxonomically homogeneous, these seasonal changes in the relative importance of each group suggest that they compete for the same similar levels of light and nutrients, since their summed biomass was relatively constant throughout the year $\left(2.6 \pm 0.1 \mathrm{mg} \mathrm{C} \mathrm{m}^{-3}\right)$.

Temporal dynamics of bacteria in temperate waters are usually quite predictable, with maxima in summer 
and minima in winter (Li 1998). Photosynthetic cyanobacteria followed this pattern as stated above, in contrast to heterotrophic bacteria (Fig. 3). Heterotrophic bacterioplankton abundance was relatively homogeneous with several weak maxima throughout the year, including one in summer as also reported by Valencia et al. (2003) in the NW Cantabrian Sea. The maximal abundances ( 1 to $2 \times 10^{6}$ cells ml $^{-1}$ ) were similar to previous values reported for the $\mathrm{N}$ and NW Iberian shelf (Barquero et al. 1998, Barbosa et al. 2001, Valencia et al. 2003, Calvo-Díaz et al. 2004). We also found a positive relationship of bacterial abundance and temperature in the 10 to $20^{\circ} \mathrm{C}$ range as reported by Unanue et al. (1992) for a nearby region, although this relationship was virtually lost above $15^{\circ} \mathrm{C}$ (Fig. 9B), similarly to the macroecological analysis of $\mathrm{Li}$ et al. (2004). The same trend was found for the 2 groups of heterotrophic bacteria (data not shown). Contrary to their frequent labelling as dormant, weakly active or even dead cells (Lebaron et at 2002), LNA bacteria would thus seem to respond to environmental changes in a similar fashion to HNA, as discussed in depth below.

Bacterial standing stock and activity are strongly affected by temperature (Li 1998), but also by the flux of dissolved organic matter (DOM) and predation. $\mathrm{Li}$ (1998) constrained the bottom-up hypothesis (i.e. regulation by substrate) to those regions with a mean annual temperature $>14^{\circ} \mathrm{C}$. In our study area the mean temperature was $15.2^{\circ} \mathrm{C}$. Although no data on DOM fluxes are available, a significant correlation between bacterial biomass and phytoplankton biomass as a proxy of primary production could be expected if bacteria were strongly dependent on recent photosynthate. The low values of the correlation coefficients found ( 0.36 for LNA and 0.34 for HNA) suggest either the existence of DOM sources other than phytoplankton-derived, as suggested for the NW Iberian shelf by Morán et al. (2002), or temporal uncoupling between both compartments, as observed by Barbosa et al. (2001).

\section{Size and pigment content of picophytoplankton}

The seasonal variation of cell size and chl a red fluorescence is similar to that found in previous reports in the Atlantic (DuRand et al. 2001), Pacific (Campbell et al. 1997) and the Mediterranean Sea (Synechococcus, Agawin et al. 1998), with minimum values at the surface and maximum at depth in summer (DuRand et al. 2001), and homogeneous values throughout the water column in winter. The size ranges of cyanobacteria were very similar to those found in other areas, although our mean values were slightly higher (DuRand et al. 2001, Worden et al. 2004).
Opposite changes in cell size and relative fluorescence with depth can reflect the presence of different subpopulations. However, the larger variation in fluorescence than in size found for cyanobacteria and picoeukaryotes suggests that these vertical changes could be due to a photoadaptative response of the same population to decreasing irradiance. Cyanobacteria and small picoeukaryotes were significantly smaller above the nutricline than below (Fig. 6A-C), but no differences were found relative to the mixed layer depth. Thus, it seems that cell size was regulated by nutrient status rather than density stratification, suggesting the hypothesis that physiological responses differed within physically continuous populations. This was further supported by a positive relationship between cell size and nutrient concentration $(\mathrm{r}=0.53$ to 0.58 for $\mathrm{NO}_{3}{ }^{-}, \mathrm{r}=0.40$ to 0.56 for $\mathrm{PO}_{4}^{-}, \mathrm{p}<0.01, \mathrm{n}=259$ [103 for Prochlorococcus]). Vertical patterns in large picoeukaryotes cell size were not observed (Fig. 6D). Together with a probably high taxonomic heterogeneity, the somewhat artificial upper size limit of this group, due to the flow cytometry settings used $(\sim 5 \mu \mathrm{m})$, must also be taken into account.

Phycobiliproteins contribute to photosynthesis by harvesting part of solar energy and transferring it to chlorophyll a. Phycoerythrin (PE), the main phycobiliprotein found in oceanic waters, is usually associated to cyanobacteria (Waterbury et al. 1986, Lantoine \& Neveux 1997), constituting their dominant accessory photosynthetic pigment. Despite the good correlation found between FL3 (red fluorescence from chl a) and FL2 (orange fluorescence from PE), a possible indicator that the chl a:PE pigment ratio was constant along the annual cycle (Neveux et al. 1999), differences in the chl a:PE ratio were also observed in vertical profiles (Fig. 8A). Although these differences could be explained by the presence of distinct strains with PE prosthetic groups in different proportions (Olson et al. 1988), the hypothesis of chromatic adaptation within the same strain due to shifts in light quality (Palenik 2001) cannot be discarded. Limiting irradiance at depth would involve a higher energy transfer efficiency to perform photosynthesis, which could be achieved by a relative increase in $\mathrm{PE}$, as observed in mixing conditions. Further analyses are, however, needed in order to fully explain these observations.

\section{Size and nucleic acid content of heterotrophic bacteria}

Both size and nucleic acid content of heterotrophic bacteria are sensitive to metabolic activity (Lebaron et al. 2002). Although slight, the relatively higher size variation of HNA bacteria compared with LNA could 
suggest a stronger response of the former group to environmental changes but then the higher $\mathrm{CV}$ of nucleic acid content of LNA bacteria remains to be explained. Gasol et al. (1995) suggested that the probability of a bacterium being active was a direct function of size. HNA bacteria are generally associated with larger size than LNA bacteria (see references in Lebaron et al. 2001) and, hence, usually assumed to be more active. However, their smaller size compared with LNA bacteria in spring and late winter was striking (Fig. 7). Recent studies show a great variability of the flow cytometer variables that characterize these 2 groups. Hence, variability in light scatter in samples taken from different aquatic ecosystems could be simply explained by the ecosystem type (J. M. Gasol pers. comm.) rather than by a different metabolic activity. Similarly to our results during most of the year, Corzo et al. (2005) observed an increase in the percentage of HNA bacteria with depth in Antarctic waters, which they attributed to a higher grazing pressure at the surface, where the most active and largest HNA cells occurred. In late winter and spring, the period of larger LNA cells (Fig. 7) corresponded in our case with a marked dominance of HNA cells $(68 \pm 1 \%)$ in the entire water column. This dominance could also be the result of selection of larger-sized cells by bacterivorous protozoa (González et al. 1990), regardless of their nucleic acid content. Bacterial size is an important factor influencing susceptibility to grazing, with both endpoints of the size range acting as a refuge from grazers (Jürgens \& Güde 1994). But a fundamental question remains: Why were LNA bacteria larger than HNA bacteria during these months? No activities or growth rates were estimated, but if we assume activity as a function of cell size (Gasol et al. 1995), a higher specific activity of LNA bacteria rather than HNA bacteria would be expected during this period. This is in agreement with recent reports where LNA bacteria also appear to be actively growing (Zubkov et al. 2001, Sherr et al. in press). Further studies are obviously needed, but our results advise for caution in the direct estimation of active or growing cells from size or nucleic acid content measurements. As recently suggested by Smith \& del Giorgio (2003), we should change our view of the structure of the bacterial community to accommodate a continuum of metabolic states and replace the present notion of 'active' versus 'inactive' cells.

\section{Picoplankton biomass}

Across-system comparisons of the biomass of planktonic groups are usually hampered by the large variations (even of orders of magnitude) in the conversion factors used in different studies. However, biovolumebased factors, like the ones used here, should always be preferred to constant conversion factors, often obtained in areas of different ecological characteristics. Although seasonal variations of size are taken into account by using volume-to-carbon conversion factors, the latter also vary widely (Fukuda et al. 1998, Worden et al. 2004). The factor used here for heterotrophic bacteria was that of Bjørnsen (1986). Had we used the allometric factor of Norland (1993), $C=120 \times V^{0.72}$, our estimates would on average be $22 \%$ lower. On the other hand, we chose Worden et al. (2004) conversion factors for picophytoplanktonic groups since their study was also carried out in a coastal zone, and they varied little between the different groups (from 230 to

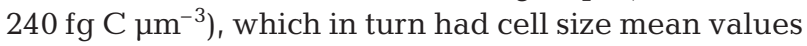
and ranges very similar to ours.

Biomass of cyanobacteria and picoeukaryotes was largely determined by cell abundances (Fig. 10A-C) rather than changes in cell size, as previously reported (DuRand et al. 2001, Worden et al. 2004). Cyanobacterial biomass virtually reached that of picoeukaryotes during summer (Table I) and even dominated in September $(55 \pm 1 \%)$, in contrast to the Pacific coastal site sampled by Worden et al. (2004), where dominance by picoeukaryotes was consistently observed during the year. Similar results have been reported in a Cantabrian Sea estuary (Ansotegui et al. 2003) using a different methodology, which suggests that the importance of cyanobacteria in coastal waters of the Bay of Biscay was not very different to that in stratified open waters (Campbell et al. 1997, DuRand et al. 2001, Liu et al. 2002). The clear dominance of picoeukaryotes in spring is in agreement with our observations in 2002 (Calvo-Díaz et al. 2004), although absolute values in the latter study should be revised downwards due to the use of constant conversion factors.

Differences in bacterial biomass between HNA and LNA bacterial groups were also largely caused by differences in abundance rather than in size. HNA bacteria dominated bacterial biomass during the study period except in June at Stn 2, and at some depths in autumn. The heterotrophic to autotrophic picoplankton biomass ratio was $>1$ during the sampled period except in September but bacterial biomass tended to be lower than total phytoplanktonic biomass except in specific samples. The bacteria to phytoplankton biomass ratio (annual mean: $0.47 \pm 0.02$ ) was in agreement with previous results obtained in these waters (Calvo-Díaz et al. 2004), but always higher than the value (0.2) suggested by Ducklow \& Carlson (1992) for coastal areas.

In spite of the peaks observed in summer and winter, and the very low values found in April 2002 and 2003, picophytoplankton contribution to photic layer inte- 
grated total biomass of phytoplankton was remarkably constant during the sampled period (mean $17 \pm 2 \%$, cf. $14 \%$ slope of the Model I regression line, Fig. 11), with no indication of the expected decrease in its relative contribution with increasing algal biomass. However, it must be borne in mind that relatively low values of phytoplanktonic biomass were recorded during the sampled period, and that reviews showing a decreasing contribution of picophytoplankton with increasing total biomass include much higher values (Bell \& Kalff 2001). These results underline the importance of smaller plankton not only under permanently stratified, oligotrophic conditions (Li et al. 1983, Li \& Harrison 2001), but also in coastal waters subjected to strong tides and with the water column mixed to the seafloor for several months during the year.

Acknowledgements. We are indebted to the captain and crew of RV 'José de Rioja', to L. Á. Suárez for his help with flow cytometry analysis and to the rest of the people at the laboratory. M. Maiques made chlorophyll a determinations and nutrient data were kindly provided by N. González and C. Carballo. A.C.-D. was a recipient of a FPI pre-doctoral fellowship from the Spanish Ministry of Education and Science. This work was supported by the Spanish research grant VARIPLACA (CICYT, REN2001-0345/MAR) and the timeseries project RADIALES from the Instituto Español de Oceanografía (IEO). We are also grateful to 2 anonymous reviewers whose comments and suggestions improved the manuscript.

\section{LITERATURE CITED}

Agawin NSR, Duarte CM, Agustí S (1998) Growth and abundance of Synechococcus sp. in a Mediterranean Bay: seasonality and relationship with temperature. Mar Ecol Prog Ser 170:45-53

Ansotegui A, Sarobe A, Trigueros JM, Urrutxurtu I, Orive E (2003) Size distribution of algal pigments and phytoplankton assemblages in a coastal-estuarine environment: contribution of small eukaryotic algae. J Plankton Res 25(4): 341-355

Barbosa AB, Galvão HM, Mendes PA, Álvarez-Salgado XA, Figueiras FG, Joint I (2001) Short-term variability of heterotrophic bacterioplankton during upwelling off the NW Iberian margin. Prog Oceanogr 51:339-359

Barquero S, Botas JA, Bode A (1998) Abundance and production of pelagic bacteria in the southern Bay of Biscay during summer. Sci Mar 62:83-90

Bell T, Kalff J (2001) The contribution of picophytoplankton in marine and freshwater systems of different trophic status and depth. Limnol Oceanogr 46:1243-1248

Bjørnsen PK (1986) Automatic determination of bacterioplankton biomass by image analysis. Appl Environ Microbiol 51:1199-1204

Brussaard CPD, Thyrhaug R, Marie D, Bratbak G (1999) Flow cytometric analyses of viral infection in two marine phytoplankton species, Micromonas pusillas (prasinophyceae) and Phaeocystis pouchetii (prymnesiophyceae). J Phycol 35:941-948

Buck KR, Chavez FP, Campbell L (1996) Basin-wide distributions of living carbon components and the inverted trophic pyramid of the central gyre of the North Atlantic Ocean, summer 1993. Aquat Microb Ecol 10:283-298
Calvo-Díaz A, Morán XAG, Nogueira E, Bode A, Varela M (2004) Picoplankton community structure along the northern Iberian continental margin in late winter-early spring. J Plankton Res 26(9):1069-1081

Campbell L, Liu H, Nolla HA, Vaulot D (1997) Annual variability of phytoplankton and bacteria in the Subtropical North Pacific Ocean at station ALOHA during the 1991-1994 E.NSO. event. Deep-Sea Res I 44:167-192

Chisholm, SW, Olson RJ, Zettler ER, Goericke R, Waterbury JB, Welschmeyer NA (1988) A novel free-living prochlorophyte abundant in the oceanic euphotic zone. Nature 334: 340-343

Corzo A, Rodríguez-Gálvez S, Lubian L, Sobrino C, Sangrá P, Martínez A (2005) Antarctic marine bacterioplankton subpopulations discriminated by their apparent content of nucleic acids differ in their response to ecological factors. Polar Biol 29:27-39

Ducklow HW, Carlson CA (1992) Oceanic bacterial production. Adv Microb Ecol 12:113-181

DuRand MD, Olson RJ (2001) Phytoplankton population dynamics at the Bermuda Atlantic time-series station in the Sargasso Sea. Deep-Sea Res II 48:1983-2003

El Hag AGD, Fogg GE (1986) The distribution of coccoid blue-green algae (Cyanobacteria) in the Menai Straits and the Irish Sea. Br Phycol J 21:45-54

Fernández E, Bode A (1991) Seasonal patterns of primary production in the Central Cantabrian Sea (Bay of Biscay). Sci Mar 55:629-636

Fernández E, Marañón E, Morán XAG, Serret P (2003) Potential causes for the unequal contribution of picophytoplankton to total biomass and productivity in oligrotrophic waters. Mar Ecol Prog Ser 254:101-109

Fukuda R, Ogawa H, Nagata T, Koike I (1998) Direct determination of carbon and nitrogen contents of natural bacterial assemblages in marine environments. Appl Environ Microbiol 64:3352-3358

Gasol JM, del Giorgio PA (2000) Using flow citometry for counting natural planktonic bacteria and understanding the structure of planktonic bacterial communities. Sci Mar 64:197-224

Gasol JM, del Giorgio PA, Massana R, Duarte CM (1995) Active versus inactive bacteria: size dependence in a coastal marine plankton community. Mar Ecol Prog Ser 128:91-97

González JM, Sherr EB, Sherr BF (1990) Size-selective grazing on bacteria by natural assemblages of estuarine flagellates and ciliates. Appl Environ Microbiol 56:583-589

Jiao N, Yang Y, Koshikawa H, Watanabe M (2002) Influence of hydrographic conditions on picoplankton distribution in the East China Sea. Aquat Microb Ecol 30:37-48

Jochem F (1988) On the distribution and importance of picocyanobacteria in a boreal inshore area (Kiel Bight, Western Baltic). J Plankton Res 10:1009-1022

Joint IR, Owens NJP, Pomroy AJ (1986) Seasonal production of photosynthetic picoplankton and nanoplankton in the Celtic Sea. Mar Ecol Prog Ser 28:251-258

Jürgens K, Güde H (1994) The potential importance of grazing-resistant bacteria in planktonic systems. Mar Ecol Prog Ser 112:169-188

Koutsikopoulos C, Le Cann B (1996) Physical processes and hydrological structures related to the Bay of Biscay anchovy. Sci Mar 60:9-19

Kuosa H (1991) Picoplanktonic algae in the Northern Baltic Sea: seasonal dynamics and flagellate grazing. Mar Ecol Prog Ser 73:269-276

Lantoine F, Neveux J (1997) Spatial and seasonal variations in abundance and spectral characteristics of phycoerythrins 
in the tropical northeastern Atlantic Ocean. Deep-Sea Res I 44:223-246

Lebaron P, Servais P, Agogué H, Courties C, Joux F (2001) Does the high nucleic acid content of individual bacterial cells allow us to discriminate between active cells and inactive cells in aquatic systems? Appl Environ Microbiol 67:1775-1782

Lebaron P, Servais P, Baudoux AC, Bourrain M, Courties C, Parthuisot N (2002) Variations of bacterial specific activity with cell-size and nucleic acid content assessed by flow cytometry. Aquat Microb Ecol 28:131-140

Li WKW (1998) Annual average abundance of heterotrophic bacteria and Synechococcus in surface ocean waters. Limnol Oceanogr 43:1746-1753

Li WKW, Harrison WG (2001) Chlorophyll bacteria and picophytoplankton in ecological provinces of the North Atlantic. Deep-Sea Res II 48:2271-2293

Li WKW, Subba Rao DV, Harrison WG, Smith JC, Cullen JJ, Irwin B, Platt T (1983) Autotrophic picoplankton in the tropical ocean. Science 219:292-295

Li WKW, Head EJH, Harrison WG (2004) Macroecological limits of heterotrophic bacterial abundance in the ocean. Deep-Sea Res I 51:1529-1540

Liu H, Suzuki K, Minami C, Saino T, Watanabe M (2002) Picoplankton community structure in the subartic Pacific Ocean and the Bering Sea during summer 1999. Mar Ecol Prog Ser 237:1-14

Mann KH, Lazier JRN (1991) Dynamical of marine ecosystems, biological-physical interactions in the oceans. Blackwell Scientific Publications, Oxford

Marie D, Partensky F, Vaulot D (1999) Enumeration of phytoplankton, bacteria, and viruses in marine samples. In: Robinson JP (ed) Current protocols in cytometry. John Wiley \& Sons, New York, p 11.11.1-11.11.15

Miyazono A, Odate T, Maita Y (1992) Seasonal fluctuations of cell density of cyanobacteria and other picophytoplankton in Iwanai Bay, Hokkaido, Japan. J Oceanogr 48:257-266

Modigh M, Saggiomo V, Ribera d'Alcalà M (1996) Conservative features of picoplankton in a Mediterranean eutrophic area, the Bay of Naples. J Plankton Res 18: 87-95

Morán XAG, Gasol JM, Pedrós-Alió C, Estrada M (2002) Partitioning of phytoplanktonic organic carbon production and bacterial production along a coastal-offshore gradient in the NE Atlantic during different hydrographic regimes. Aquat Microb Ecol 29:239-252

Neveux J, Panouse M (1987) Spectrofluorometric determination of chlorophylls and pheophytins. Arch Hydrobiol 109: 567-581

Neveux J, Lantoine F, Vaulot D, Marie D, Blanchot J (1999) Phycoerythrins in the southern tropical and equatorial Pacific ocean: evidence for new cyanobacterial types. J Geophys Res 104(C2):3311-3321

Olson RJ, Chisholm SW, Zettler ER, Armbrust EV (1988) Analysis of Synechococcus pigment types in the sea using single and dual beam flow cytometry. Deep-Sea Res 35: 425-440

Palenik B (2001) Chromatic adaptation in marine Synechococcus strains. Appl Environ Microbiol 67:991-994

Partensky F, Blanchot J, Vaulot D (1999) Differential distribution and ecology of Prochlorococcus and Synechococcus in oceanic waters: a review. In: Charpy L, Larkum AWD (eds) Marine cyanobacteria and related organisms. Bull Inst Oceanogr Monaco 19:431-449

Peliz Á, Dubert J, Haidvogel DB, Le Cann B (2003) Generation and unstable evolution of a density-driven Eastern Poleward Current: The Iberian Poleward Current. J Geo- phys Res 108(C8):3268

Pingree RD, LeCann B (1990) Structure, strength and seasonality of the slope currents in the Bay of Biscay region. J Mar Biol Assoc UK 70:857-885

Raven JA (1986) Physiological consequences of extremely small size for autotrophic organisms in the sea. In: Platt T, Li WKW (eds) Photosynthetic Picoplankton. Can Bull Fish Aquat Sci 214:1-70

Ricker WE (1973) Linear regression in fishery research. J Fish Res Board Can 30:409-434

Rodriguez F, Fernandez E, Head RN, Harbour DS, Bratbak G, Heldal M, Harris RP (2000) Temporal variability of viruses, bacteria, phytoplankton and zooplankton in the western English Channel off Plymouth. J Mar Biol Assoc UK 80(4): 575-586

Shalapyonok A, Olson RJ, Shalapyonok LS (2001) Arabian Sea phytoplankton during Southwest and Northeast Monsoon 1995: composition, size structure and biomass from individual cell properties measured by flow cytometry. Deep-Sea Res II 48:1231-1261

Sherr EB, Sherr BF, Longnecker K (in press) Distribution of bacterial abundance and cell-specific nucleic acid content in the Northeast Pacific Ocean. Deep-Sea Res

Shimada A, Nishijima M, Maruyama T (1995) Seasonal appearance of Prochlorococcus in Surugay Bay, Japan in 1992-1993. J Oceanogr 51:289-300

Smith EM, del Giorgio PA (2003) Low fractions of active bacteria in natural aquatic communities? Aquat Microb Ecol 31:203-208

Tarran GA, Zubkov MV, Sleigh MA, Burkill PH, Yallop M (2001) Microbial community structure and standing stocks in the NE Atlantic in June and July of 1996. Deep-Sea Res II 48:963-985

Troussellier M, Courties C, Lebaron P, Servais P (1999) Flow cytometric discrimination of bacterial populations in seawater based on SYTO 13 staining of nucleic acids. FEMS Microbiol Ecol 29:319-330

Unanue M, Ayo B, Azúa I, Barcina I, Iriberri J (1992) Temporal variability of attached and free-living bacteria in coastal waters. Microb Ecol 23:27-39

Valencia J, Abalde J, Bode A, Cid A and 5 others (2003) Variations in planktonic bacterial biomass and production, and phytoplankton blooms off A Coruña (NW Spain). Sci Mar 67:143-153

Waterbury JB, Watson SW, Guillard RRL, Brand LE (1979) Widespread occurrence of a unicellular, marine, planktonic, cyanobacterium. Nature 277:293-294

Waterbury JB, Watson SW, Guillard RRL, Brand LE (1986) Biological and ecological characterization of the marine unicellular cyanobacterium Synechococcus. In: Platt T, Li WKW (eds) Photosynthetic picoplankton. Can Bull Fish Aquat Sci 214:71-120

Worden AZ, Nolan JK, Palenik B (2004) Assessing the dynamics and ecology of marine picophytoplankton: the importance of the eukaryotic component. Limnol Oceanogr 49: 168-179

Zubkov MV, Sleigh MA, Tarran GA, Burkill PH, Leakey RJG (1998) Picoplankton community structure on an Atlantic transect from $50^{\circ} \mathrm{N}$ to $50^{\circ} \mathrm{S}$. Deep-Sea Res I 45:1339-1355

Zubkov MV, Sleigh MA, Burkill PH (2000) Assaying picoplankton distribution by flow cytometry of underway samples collected along a meridional transect across the Atlantic Ocean. Aquat Microb Ecol 21:13-20

Zubkov MV, Fuchs BM, Burkill PH, Amann R (2001) Comparison of cellular and biomass specific activities of dominant bacterioplankton groups in stratified waters of the Celtic Sea. Appl Environ Microbiol 67:5210-5218 